\title{
SENIORZY I STARZENIE SIE W POLSKIEJ POLITYCE RODZINNEJ
}

\begin{abstract}
Streszczenie
Współczesnym problemem społecznym jest proces starzenia się społeczeństwa i wzrastająca populacja osób starszych. Konsekwencje tych zjawisk mają charakter jednostkowy i społeczny. Wyznaczaja obraz społeczeństwa polskiego (malejaca liczba ludności, malejąca dzietność, wzrost liczby osób starszych i sędziwych, malejąca liczba dzieci, młodzieży i osób w wieku produkcyjnym). Stanowia wyzwanie z jednej strony dla rzadu - jak organizować pomoc i opieke seniorom, z drugiej zaś dla samych seniorów i ich rodzin-jak podnosić jakość ich życia.

$W$ artykule omówiono proces starzenia się społeczeństwa, przedstawiono portret polskiego seniora oraz wskazano działania polityki rodzinnej w zakresie pomocy i aktywizacji osób starszych.
\end{abstract}

Słowa kluczowe: starość, proces starzenia się społeczeństwa polskiego, polityka rodzinna, senior, emeryt

\section{Wstęp}

Starzenie się jest naturalnym procesem i etapem w życiu człowieka. Choć w sensie formalnym definicja starości nie zmienia się, tak w społecznym odbiorze od lat obserwowane jest przesuwanie się granic młodości i starości. O ile w 1998 r. respondenci uznali, że młodość kończy się w wieku blisko 35 lat, tak w 2012 r. w wieku blisko 37 lat. Z kolei starość według ankietowanych z 1998 r. zaczyna się w 60. roku życia, zaś według ankietowanych z 2012 r. - po przekroczeniu 63 roku

* Małgorzata Szyszka - dr n. hum. w zakresie socjologii, Wydział Nauk Społecznych, Katolicki Uniwersytet Lubelski Jana Pawła II w Lublinie. 
życia ${ }^{1}$. Opinia ta odzwierciedla zmiany demograficzne i przemiany społecznego postrzegania kwestii starzenia się związane z jej konsekwencjami. Współcześnie jest to jedno z priorytetowych zagadnien - depopulacja ludności Polski i proces starzenia się społeczeństwa.

Celem artykułu jest wskazanie, co współcześnie oznacza starość w jednostkowym i społecznym wymiarze. Punktem wyjścia do analiz będzie proces starzenia się społeczeństwa oraz prognozy demograficzne. Przedstawiony zostanie portret polskiego seniora pod kątem cech społeczno-demograficznych i podejmowanych aktywności. W ostatniej zaś części uwaga będzie skupiona na działaniach polityki rodzinnej wobec seniorów i wyzwaniach, jakie stoją przed rządem, wynikających ze zwiększającej się liczby osób starszych w społeczeństwie.

\section{Starzenie się społeczeństwa}

Przemiany w strukturze demograficznej społeczeństwa polskiego obserwuje się od lat, ale tempo owych przemian w ostatnich dwóch dekadach jest tak intensywne, jak niepokojące. Niepokój o potencjał demograficzny Polski wynika z depopulacji jako rezultatu ubytku naturalnego i migracyjnego, depresji urodzeniowej, relatywnie wysokiej częstości zgonów oraz niekorzystnych przekształceń w strukturze ludności według wieku². Demografowie wskazują wręcz, że Polska wkroczyła w okres kryzysu demograficznego, który może mieć trwały charakter. Wyrazem tegoż kryzysu są między innymi zmiany w strukturze wieku ludności (wykres 1). Zmniejsza się liczba osób w wieku produkcyjnym, zmniejsza się liczba dzieci i młodzieży (w wyniku spadku urodzeń), rośnie natomiast udział ludności w wieku poprodukcyjnym (kobiety 60+, mężczyźni 65+), a zwłaszcza osób w wieku sędziwym (80 lat i więcej). Ta sytuacja z kolei jest spowodowana wydłużaniem się trwania życia Polaków. Przeciętne trwanie życia dla mężczyzn wynosi obecnie ponad 73 lata, zaś dla kobiet ponad 81 lat. Jest to tendencja rosnąca. W porównaniu z początkiem lat 90 . XX wieku przeciętne trwanie życia wydłużyło się dla mężczyzn o 7,7 lat, a dla kobiet o 6,5 lat. Porównania z połową XX wieku wypadają jeszcze korzystniej - obecnie mężczyźni w Polsce żyją o 17,5 lat dłużej niż w połowie ubiegłego stulecia, natomiast kobiety o prawie 20 lat dłużej ${ }^{3}$. Jest to trend jednoznacznie wskazujący na proces starzenia się społeczeństwa polskiego.

\footnotetext{
Polacy wobec własnej starości, Komunikat CBOS, Warszawa 2012, s. 3.

2 J. Hrynkiewicz, Aktualna sytuacja demograficzna Polski, w: Perspektywy demograficzne jako wyzwanie dla polityki ludnościowej, red. J. Hrynkiewicz, A. Potrykowska, Rządowa Rada Ludnościowa, Warszawa 2016, s. 14-23.

3 Trwanie życia w 2015 r, GUS, Warszawa 2016, s. 19.
} 


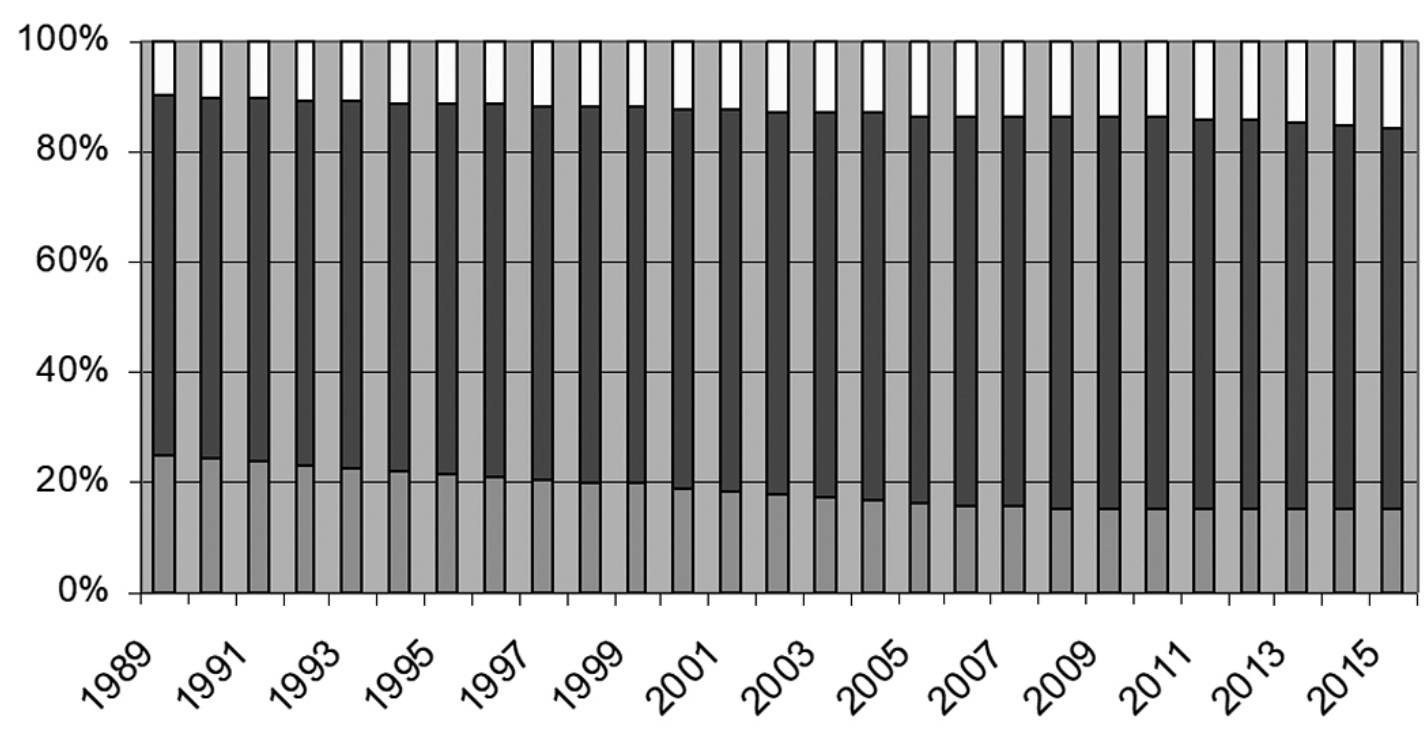

\section{$0-14 \square 15-64 \square 65+$}

Wykres 1. Struktura ludności według wieku w latach 1989-2015

Źródło: GUS, http://stat.gov.pl/obszary-tematyczne/ludnosc/ludnosc/struktura-ludnosci,16,1.html.

Rośnie współczynnik starości, czyli udział ludności w wieku 65 i więcej lat w ogólnej populacji. Osoby w wieku $65+$ stanowią w Polsce ponad $15 \%$ populacji (2014 r.), jednakże - jak wskazuje prognoza Eurostatu - w 2050 r. współczynnik ten wyniesie ponad 30\%. Ponadto udział najstarszej grupy osób (80 lat i więcej) w ogólnej populacji Polski, który wynosi niespełna 4\%, zwiększy się w 2050 r. do prawie $10 \%{ }^{4}$. Zwiększy się zatem nie tylko liczba i odsetek ludności w wieku 65 i więcej lat, ale także liczba i odsetek osób w wieku 80 lat i więcej. Nastąpi więc przyspieszenie tempa procesu podwójnego starzenia ${ }^{5}$.

Poziom zaawansowania procesu starzenia się ludności obrazuje kwestia zastępowalności pokoleń. Jedną z miar jest indeks starości przedstawiający relację „pokolenia dziadków” (65 i więcej lat) do „pokolenia wnuczków” (0-14 lat). „W przypadku Polski relacja ta wynosi 103, co oznacza prawie równowagę liczebną

4 J. Stańczak, D. Szałtys, Sytuacja demograficzna Polski na tle Europy, w: Perspektywy demograficzne jako wyzwanie dla polityki ludnościowej, red. J. Hrynkiewicz, A. Potrykowska, Rządowa Rada Ludnościowa, Warszawa 2016, s. 43-47.

5 M. Waligórska, J. Witkowski, Prognoza demograficzna Polski do 2050 rokunowe ujęcie, w: Perspektywy demograficzne jako wyzwanie dla polityki ludnościowej, red. J. Hrynkiewicz, A. Potrykowska, Rządowa Rada Ludnościowa, Warszawa 2016, s. 56. 


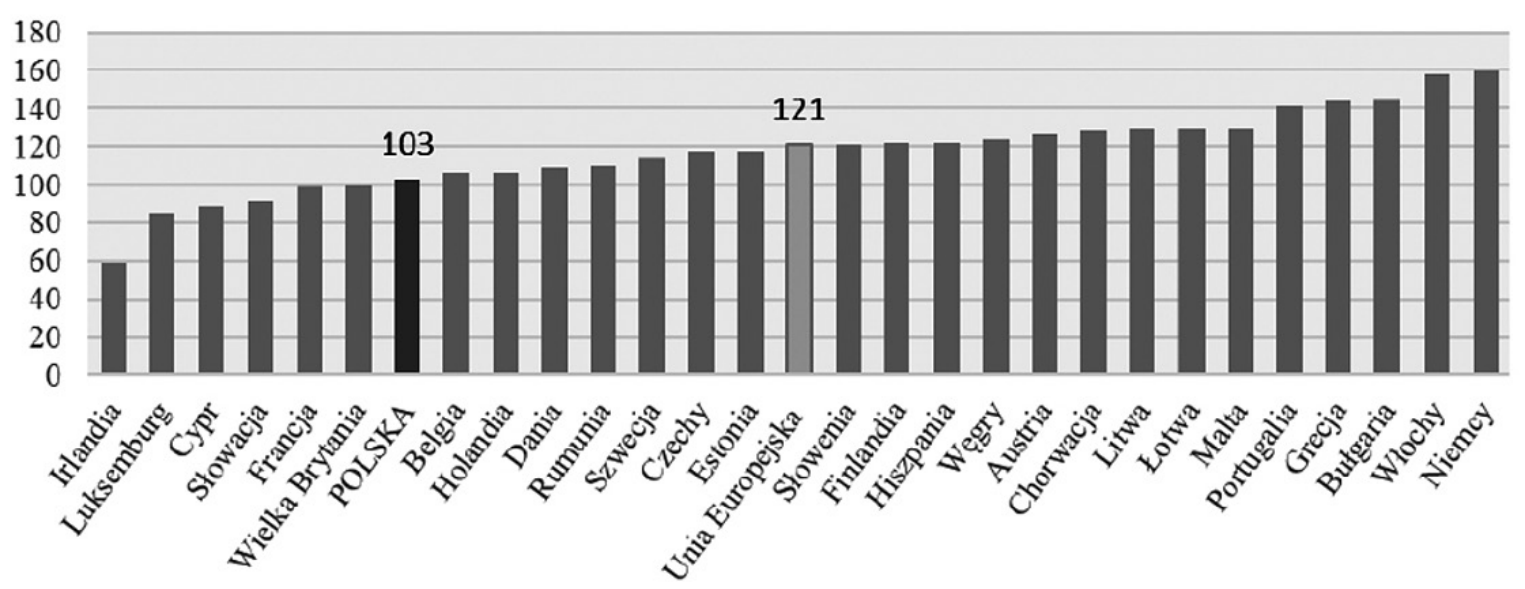

Wykres 2. Indeks starości w krajach Unii Europejskiej w 2014 r.

Źródło: J. Stańczak, D. Szałtys, Sytuacja demograficzna Polski na tle Europy, w: Perspektywy demograficzne jako wyzwanie dla polityki ludnościowej, red. J. Hrynkiewicz, A. Potrykowska, Rządowa Rada Ludnościowa, Warszawa 2016, s. 46.

między dziadkami i wnukami (wykres 2$)^{6}$. Ta pozornie korzystna - w odniesieniu do innych krajów UE - obecna sytuacja demograficzna Polski zmieni się diametralnie już w ciągu najbliższej dekady, a w 2050 r. Polska stanie się jednym z krajów Europy o najbardziej zaawansowanym procesie starzenia się populacji”’7.

Dostęp do usług medycznych i opiekuńczych oraz coraz lepsza ich jakość będzie wpływać na dalsze systematyczne wydłużanie życia, a tym samym na przyśpieszenie tempa starzenia się ludności ${ }^{8}$. Zasadniczo, „starzenie się ludności

6 Najmniej korzystna relacja pokoleniowa występuje w Niemczech i we Włoszech, gdzie na 100 wnuków przypada po prawie 160 dziadków, natomiast w Irlandii zdecydowanie przeważają dzieci - każdej setce z nich odpowiada ok. 60 dziadków. J. Stańczak, D. Szałtys, Sytuacja demograficzna Polski ...., dz. cyt., s. 46.

7 Tamże.

8 W zmianach struktury znakomicie widać wpływ wyżów i niżów urodzeń z przeszłości. Do 2025 r. będzie wzrastał udział „młodszej” subpopulacji $65-79$ lat, bowiem tę grupę osób starszych będą sukcesywnie zasilały osoby urodzone w latach 1949-1965, a jednocześnie będzie ubywało osób w wieku 80 lat i więcej urodzonych w latach 1934-1945. Po 2025 r. drastycznie wzrośnie odsetek osiemdziesięciolatków i starszych, z uwagi na fakt, że ten wiek w kolejnych latach osiągną osoby urodzone w 1945 r. i później, a więc „pochodzące” z powojennego boomu urodzeń, zaś echo tego wyżu zasili grupę osób w wieku 65 lat i więcej. W 2040 r. osoby ponad osiemdziesięcioletnie będą stanowiły aż 36\% zbiorowości osób starszych (65 lat i więcej). W końcu prognozowanego okresu proporcje nieco ulegną zmianie i odsetek osób 80+ w ogólnej populacji osób starszych (65 i więcej) zmniejszy się do 32\%. W liczbach bezwzględnych wykazywana w bieżących bilansach ludności liczba osób w wieku 80 lat i więcej - blisko 1,5 mln w 2013 r., wzrośnie w 2050 


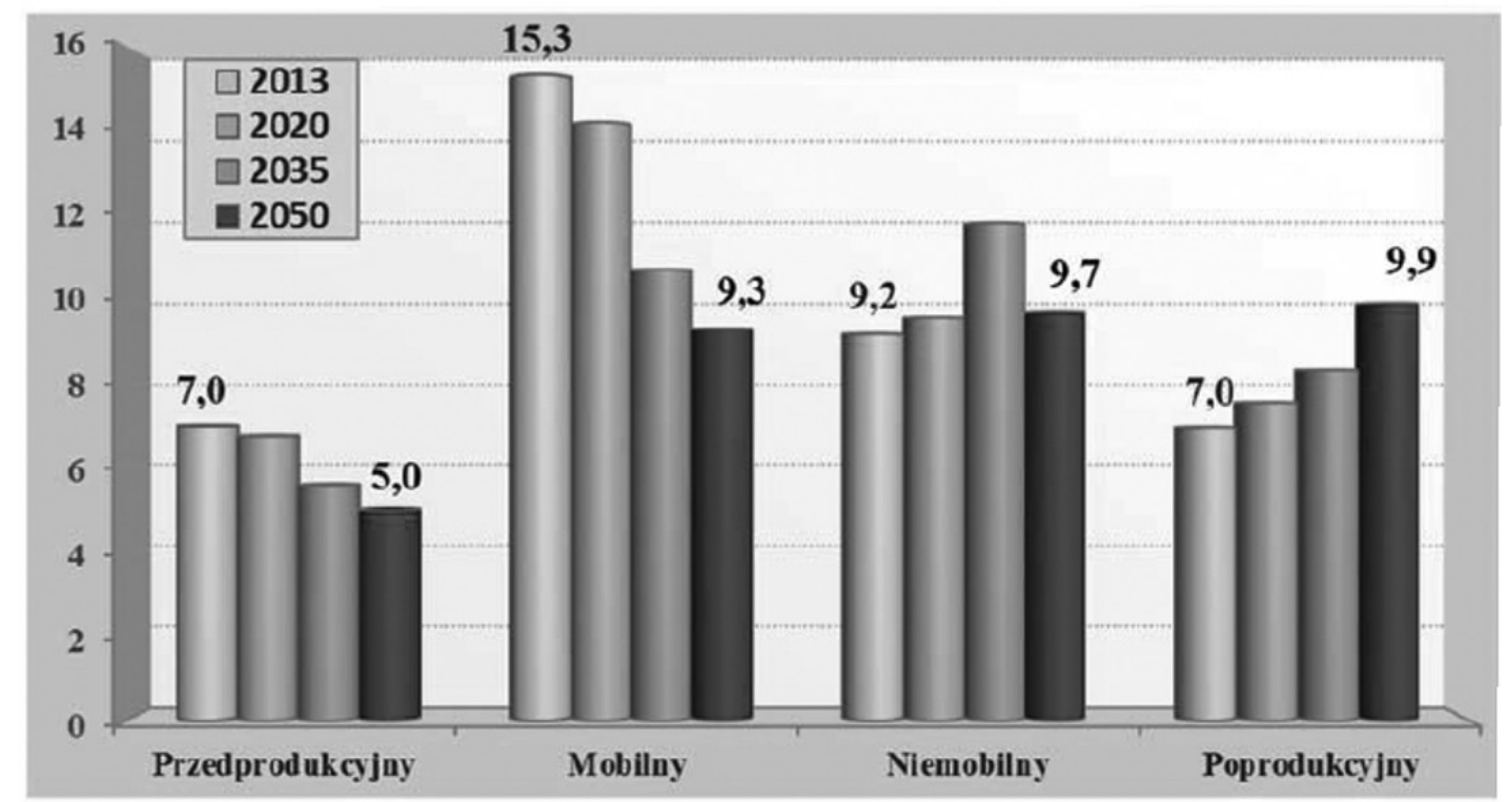

Wykres 3. Ludność według ekonomicznych grup wieku (w mln)

Źródło: Prognoza ludności na lata 2014-2050, GUS, Warszawa 2014, s. 151.

jest procesem globalnym i nieodwracalnym, silnie zróżnicowanym regionalnie. Im wyższy bowiem jest stopień rozwoju społeczno-ekonomicznego kraju, tym wyższe zaawansowanie starzenia się ludności (...) Jednocześnie dożywanie starości nie jest już „zarezerwowane” dla niewielu osób (demokratyzacja starości), ale dotyczy rosnącej części populacji, co przekłada się również na coraz większą heterogeniczność zbiorowości osób starszych"”.

Prognozy demograficzne zatem wskazują na postępujący proces zmian w strukturze wieku ludności (wykres 3). Najbardziej prawdopodobne przeobrażenia do 2050 r. spowodują wspomniany już postępujący proces starzenia się ludności Polski, a więc starzenie się ludności w wieku produkcyjnym, malejącą liczbę dzieci i młodzieży oraz ubytek kobiet w wieku prokreacyjnym. Przewidywane trendy mogą ulec modyfikacji pod wpływem założonej polityki rodzinnej i ludnościowej

r. ponad dwukrotnie - do poziomu ponad $3,5 \mathrm{mln}$, przy czym $60 \%$ ludności w podeszłym wieku będzie mieszkało w miastach. Uwzględniając strukturę według płci w końcu prognozowanego okresu 64\% będą stanowiły kobiety. Prognoza ludności na lata 2014-2050, GUS, Warszawa 2014, s. 136.

9 A. Abramowska-Kmon, O nowych miarach zaawansowania procesu starzenia sie ludności, „Studia Demograficzne” 2011, nr 1 (159), s. 3-22. 
(Program 500+), jednak modyfikacja będzie polegać na zwolnieniu tempa przemian, bo na odwrócenie trendów jest za późno ${ }^{10}$.

Z punktu widzenia interesu społecznego obecna i przyszła sytuacja demograficzna Polski jest bardzo niekorzystna, a za jeden z kluczowych problemów przyjmuje się omawiany proces starzenia się społeczeństwa.

\section{Portret polskiego seniora}

Zbiorowość osób starszych nie jest jednorodna, dlatego też z uwagi na długość przedziału wiekowego stosuje się różne jej podziały. WHO wyróżnia trzy etapy życia: 60-74 lat „młoda” starość (trzeci wiek, young old, w świetle prawa nabycie praw emerytalnych), 75-89 lat „dojrzała” starość (czwarty wiek, old old ) oraz 90 lat i więcej - długowieczność (oldest old, long life). W demografii natomiast stosuje się podział na młodszy (60-69 lat) i starszy (70-79 lat) wiek poprodukcyjny oraz starość sędziwą (80 lat $\mathrm{i}$ więcej) ${ }^{11}$. Wymienione przedziały charakteryzują (w mniejszym bądź większym stopniu) dwie determinanty: feminizacja i singularyzacja starości. Feminizacja wskazuje na znaczną przewagę odsetka kobiet nad mężczyznami. „Wśród populacji w starszym wieku większość stanowią właśnie kobiety (ponad 61\%), co oznacza, iż na 100 mężczyzn przypada 160 kobiet (dla całej ludności Polski wskaźnik feminizacji wynosi 107). Przewaga liczebna kobiet wzrasta wraz z przechodzeniem do kolejnych grup podeszłego wieku, np. w grupie wieku 65-69 lat kobiety stanowią 56\% zbiorowości i współczynnik feminizacji wynosi 126, a wśród osób co najmniej 80-letnich już 70\% to kobiety i na 100 mężczyzn przypada ich $228^{\prime \prime}$.

Drugą cechą charakteryzującą polskich seniorów jest ich stan cywilny. Pozostają oni najczęściej w związkach małżeńskich lub są wdowami/wdowcami. Jednakże i pod tym względem występuje zróżnicowanie zbiorowości kobiet i mężczyzn na skutek wyższej umieralności mężczyzn. „Ponad 3/4 populacji mężczyzn w wieku 65 lat i więcej żyje w związkach małżeńskich, podczas gdy kobiety w tej grupie wieku są najczęściej wdowami (58\%). Odsetek osób owdowiałych jest wśród kobiet 3,5-krotnie wyższy niż w porównywalnej zbiorowości mężczyzn (gdzie

10 M. Waligórska, J. Witkowski, Prognoza demograficzna Polski..., dz. cyt., s. 56, 66.

11 Prognoza ludności na lata 2014-2050, dz. cyt., s. 135; M. Adamczyk, Aktywnie ku emeryturze, Lublin 2015, s. 19-20; Zob. Aspekty medyczne, psychologiczne, socjologiczne i ekonomiczne starzenia się ludności w Polsce, red. M. Mossakowska, A. Więcek, P. Błędowski, Poznań 2012.

12 Sytuacja demograficzna osób starszych i konsekwencje starzenia sięludności Polski w świetle prognozy na lata 2014-2050, GUS, Warszawa 2014, s. 4. 
wynosi niewiele ponad 16\%). Natomiast kobiety zamężne w tym wieku stanowią $34 \%$. W miarę przechodzenia do starszych roczników wieku proces nasila się, np. w grupie osób liczących 80 lat i więcej żonaci mężczyźni stanowią jeszcze $62 \%$, a kobiety-wdowy już $80 \%$. Starość więc dla mężczyzn w większości to życie z drugą osobą, a dla kobiet - najczęściej samotność"13. Zatem singularyzacja starości oznacza samotne zamieszkiwanie (gospodarstwa jednoosobowe) głównie starszych kobiet ${ }^{14}$. Ogółem, blisko co trzecie gospodarstwo domowe w Polsce tworzą wyłącznie osoby w wieku powyżej 65 lat, a niemal 80\% tych gospodarstw tworzą kobiety (najczęściej wdowy) ${ }^{15}$.

Niemal pełna subpopulacja osób starszych posiada własne źródło utrzymania i jest to niezarobkowe źródło (emerytura $-86 \%$ lub renta $-8 \%$ ). Zdecydowanie więcej mężczyzn utrzymuje się z emerytur, kobiet zaś z rent (11,3\% kobiet wobec 2,4\% mężczyzn). Obecnie niewielki jest udział osób starszych posiadających dwa źródła dochodu - częściej są to mężczyźni i mieszkańcy miast łączący emeryturę $\mathrm{z}$ aktywnością zawodową ${ }^{16}$. Kontynuowanie pracy w wieku $60+$ jest powiązane z poziomem wykształcenia. $96 \%$ osób z wykształceniem podstawowym nie podejmuje pracy (stałej, dorywczej, czy w niepełnym wymiarze czasu). W grupie osób legitymujących się wykształceniem zasadniczym zawodowym lub średnim odsetek ten spada odpowiednio do $85 \%$ i 84\%, najniższy jest zaś wśród najlepiej wykształconych. W tej grupie $22 \%$ Polaków w wieku $60+$ pracuje w pełnym wymiarze czasu, a $70 \%$ nie podejmuje żadnej pracy ${ }^{17}$. Opisując pokolenie seniorów pod kątem poziomu wykształcenia okazuje się, że jedną z najbardziej charakterystycznych cech społecznych polskich seniorów jest niski poziom wykształcenia. 42\% osób w wieku 65 lat i więcej posiada wykształcenie podstawowe. Prawdopodobnie jest to ostatnie pokolenie seniorów z wykształceniem na takim poziomie ${ }^{18}$. Podnosi się i będzie się podnosił poziom wykształcenia osób w wieku emerytalnym, gdyż każdy kolejny rocznik wchodzący w wiek emerytalny będzie się charakteryzował coraz wyższym poziomem wykształcenia oraz coraz większym zakresem wiedzy

13 Tamże, s. 7.

14 Po 60. roku życia wskaźnik jednoosobowych gospodarstw rośnie w porównaniu z młodszymi pokoleniami trzyipółkrotnie (z 6\% wśród osób w wieku 18-59 lat do 21\% w grupie 60+). Portret społeczno-demograficzny seniorów, Komunikat CBOS, Warszawa 2016, s. 13.

15 Sytuacja demograficzna osób starszych..., dz. cyt., s. 13.

16 Tamże, s. 22-25.

17 Portret społeczno-demograficzny seniorów, dz. cyt., s. 6.

18 Tamże, s. 4; por. Sytuacja demograficzna osób starszych i konsekwencje starzenia się ludności Polski w świetle prognozy na lata 2014-2050, GUS, Warszawa 2014. 


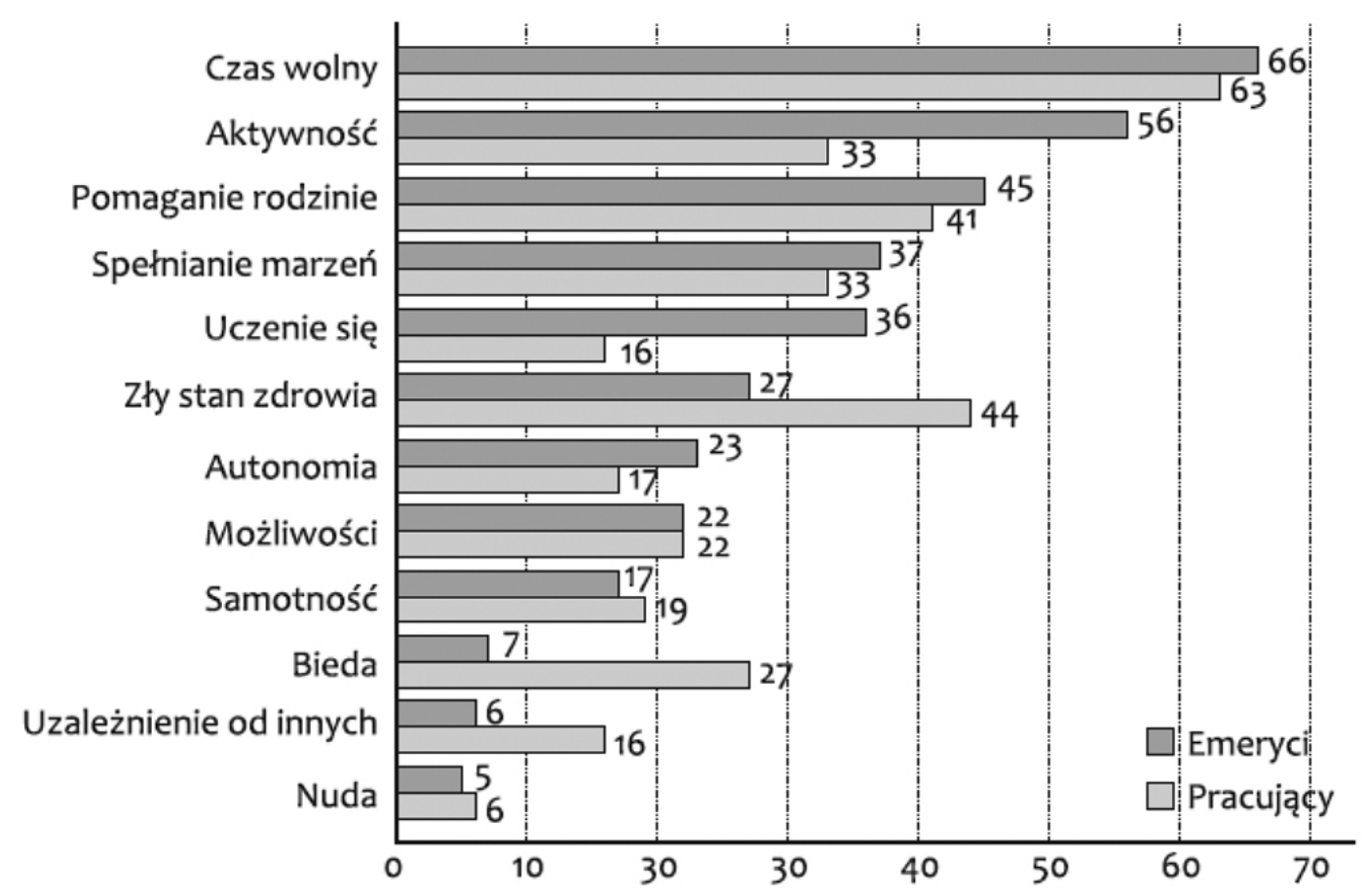

Wykres 4. Skojarzenia związane ze starością (w \%)

Źródło: M. Adamczyk, Aktywnie ku emeryturze, Lublin 2015, s. 60.

wyniesionej z dodatkowych kursów, szkoleń i innych zajęć w ramach uczenia się przez całe życie ${ }^{19}$.

Czy Polacy myślą o własnej starości? Blisko 3/4 tak, przy czym co piąta osoba (22\%) dość często, a prawie dwie piąte (38\%) rzadko. Oczywiście zainteresowanie własną starością wzrasta wraz z wiekiem - często o starości myśli co dwunasty respondent mający od 18 do 24 lat, a prawie co drugi powyżej 55 roku życia ${ }^{20}$.

Zasadniczo, jak wynika z badań M. Adamczyk, skojarzenia ze starością różnicuje wiek. Starość lepiej oceniają osoby będące już na emeryturze niż osoby jeszcze aktywne zawodowo (wykres 4). Choć obie grupy wskazują zarówno na pozytywne, jak i negatywne asocjacje ze starością i dla większości z nich starość wiąże się przede wszystkim z czasem wolnym (po $2 / 3$ wskazań), to osoby pracujące częściej wskazują na negatywne skojarzenia - zły stan zdrowia, biedę, uzależnienie od innych, samotność, czy nudę. Z kolei dla emerytów starość to aktywność, pomaganie rodzinie, spełnianie marzeń, uczenie się, autonomia i możliwości ${ }^{21}$. Być może takie postrzeganie starości wynika z obaw przed tym okresem życia.

19 P. Błędowski, J. Czapiński, Aktywność społeczna osób starszych w kontekście percepcji Polaków. Diagnoza Społeczna 2013, Warszawa 2014, s. 26.

20 Polacy wobec własnej starości, dz. cyt., s. 1-2.

21 M. Adamczyk, Aktywnie ku emeryturze, Lublin 2015, s. 60. 
Jak pokazują badania CBOS z 2012 r., Polacy myśląc o swojej starości najbardziej obawiają się chorób i niedołężności (73\%) oraz utraty samodzielności i bycia ciężarem dla innych (56\%). Jedna trzecia ankietowanych obawia się złych warunków życia, trudności z utrzymaniem się, a także samotności i utraty osób bliskich. Obawy związane są ponadto z niepewnością, z kim będą mieszkać i pod czyją będą opieką $(16 \%)^{22}$.

Są to częściowo uzasadnione obawy. Biorąc pod uwagę choćby stan zdrowia, który w przypadku najstarszej części społeczeństwa nie jest zadowalający. Większość osób starszych ocenia swoje zdrowie jako takie sobie, ani dobre ani złe (43\%), 29\% - jako złe i bardzo złe, a tylko $28 \%$ jako bardzo dobre i dobre. Oceny własnego zdrowia pogarszają się wraz z upływem lat życia. Wśród sześćdziesięciolatków co trzecia osoba oceniła swoje zdrowie jako bardzo dobre lub dobre, a tylko co piąta jako złe lub bardzo złe, natomiast wśród osób najstarszych (80 lat i więcej) co druga osoba deklarowała zły lub bardzo zły stan swojego zdrowia, a tylko co ósma - co najmniej dobry stan zdrowia ${ }^{23}$.

Także ocena możliwości samodzielnego funkcjonowania (zdolność do samoobsługi i wykonywania czynności domowych) wskazuje na występowanie trudności. Z badania GUS wynika, iż co trzecia starsza osoba (65+) ma ograniczenia w wykonywaniu codziennych czynności związanych z samoobsługą (mycie się, ubieranie, jedzenie posiłków, wstawanie z łóżka). Poziom codziennej samoobsługi maleje wraz z wiekiem - wśród najstarszych problemy z samoobsługą deklarowały już trzy osoby z pięciu. Niestety, blisko $45 \%$ osób starszych mających problemy z podstawową samoobsługą musi sobie radzić sama, bo nie ma żadnej pomocy. Także w przypadku prowadzenia gospodarstwa domowego seniorzy mają problemy. Występujące ograniczenia zdrowotne nie pozwalają bowiem co drugiej osobie starszej wykonywać okazjonalnie ciężkich prac domowych, a co trzeciej sprawia trudność robienie codziennych zakupów, zaś w dalszej kolejności wykonywanie lżejszych prac domowych, czy też dbanie o sprawy administracyjno-finansowe. Możliwość wykonywania samodzielnie tych czynności ze względów oczywistych maleje wraz z wiekiem ${ }^{24}$. „Granicą, po przekroczeniu której trudności codziennego funkcjonowania ujawniają się z większą siłą, jest wejście w drugą fazę starości, określaną jako starzy starzy (old old), czyli 75+. To wówczas pogarsza się stan

22 Polacy wobec własnej starości, dz. cyt., s. 6-7.

23 Ludność $w$ wieku 60+. Struktura demograficzna $i$ zdrowie, GUS, Warszawa 2016, s. 13. http://stat.gov.pl/obszary-tematyczne/ludnosc/ludnosc/ ludnosc-w-wieku-60-struktura-demograficzna-i-zdrowie, 24,1.html.

24 Tamże, s. 16-18. 
fizyczny wielu seniorów, utrudniając im wyjście z domu oraz nasila się poczucie osamotnienia" ${ }^{25}$.

Wskazywane przez respondentów zaniepokojenie sytuacją materialną seniorów i ewentualnym zubożeniem częściowo potwierdzają badania. Częściowo, ponieważ z jednej strony ponad jedna trzecia starszych osób uzyskuje dochód niższy niż 1200 zł miesięcznie, jednakże z drugiej strony ogólna sytuacja materialna osób starszych jest tylko nieznacznie gorsza od sytuacji większości osób młodszych, a jeśli chodzi o skrajne ubóstwo jest nawet dużo lepsza. Zakres skrajnego ubóstwa jest ponad dwukrotnie mniejszy wśród seniorów $(2,9 \%)$ niż w gospodarstwach osób młodszych (6,9\%). Oczywiście sytuacja materialna seniorów pozostaje w ścisłym związku z ich poziomem wykształcenia. Wykształcenie policealne i wyższe pozwala na ośmiokrotne zmniejszenie zagrożenia ubóstwem w stosunku do wykształcenia podstawowego. Sami seniorzy dość pozytywnie oceniają własną sytuację materialno-finansową. Ok. $60 \%$ ankietowanych jest z niej zadowolonych i dość zadowolonych, $60 \%$ dobrze ocenia swoją sytuację mieszkaniową, przy czym gospodarstwa domowe, których głową jest mężczyzna są znacznie lepiej wyposażone niż gospodarstwa kobiet. Jak prognozuje Diagnoza Spoleczna wraz ze wzrostem w kolejnych generacjach seniorów osób z wyższym wykształceniem powinna rosnąć także zamożność tej grupy ${ }^{26}$.

Podobnie często deklarowane obawy przed samotnością w starszym wieku nie znajdują potwierdzenia w badaniach. Jest to oczywiście subiektywna ocena, niemniej jednak $3 / 4$ badanych seniorów (65+) nie odczuwało w ciągu ostatnich 12 miesięcy osamotnienia. Często takie poczucie ma tylko $4 \%$ badanych $^{27}$. Dowodziłoby to, że seniorzy posiadają bliskie więzi rodzinne bądź przyjacielskie albo (i) realizują potrzebę kontaktu w inny sposób, np. poprzez Kościól, Uniwersytety Trzeciego Wieku, kluby seniora, czy inne formy aktywności. Wraz z wiekiem wzrasta częstość udziału w praktykach religijnych. $64 \%$ osób w wieku 75 lat i więcej praktykuje raz w tygodniu lub częściej (53\% w grupie wiekowej 60-65 lat) ${ }^{28}$.

Istotną formą aktywności polskich seniorów jest pomoc dzieciom i wnukom. Dziadkowie realizują tym samym jeden z rodzajów transferów międzypokoleniowych, tzw. transfery w dół (od dziadków/rodziców do wnuków/dzieci, drugi rodzaj to transfery w górę-od dzieci/wnuków do rodziców/dziadków). W ramach oferowanego wsparcia zachodzą zarówno transfery materialne (wsparcie finansowe

25 Seniorzy a młodsze pokolenia - problemy życia codziennego, Komunikat CBOS, Warszawa 2015, s. 9.

26 P. Błędowski, J. Czapiński, Aktywność społeczna osób starszych..., dz. cyt., s. 12-21.

27 Tamże, s. 8.

28 Portret społeczno-demograficzny seniorów, dz. cyt., s. 11. 
np. pokrycie kosztów zamieszkania, kształcenia, nagłych kryzysów), jak i transfery niematerialne, opierające się na zasadach solidarności i wzajemności (opieka, porady i wsparcie emocjonalne), odnoszące się (ale też budujące) więzi między członkami rodziny (np. wspólne wyjścia, rozmowy telefoniczne, odwiedziny) ${ }^{29}$. $\mathrm{Z}$ badań J. Brannen, P. Mossa i A. Mooney wśród rodzin wielopokoleniowych wynika, iż transfery w dół są znacznie częstsze i większe niż transfery w górę ${ }^{30}$. Analizy M. Kalbarczyk i A. Nicińskiej wskazują, że 40\% opieki nad wnukami udzielanej przez polskich dziadków (w 32\% przez babcie) odbywa się prawie codziennie. Opiekę nad wnuczętami sprawują nie tylko osoby na emeryturze ( $40 \%$ wszystkich emerytów, z czego w $66 \%$ są to kobiety), ale często też osoby zatrudnione lub samozatrudnione $(62 \%)^{31}$. Pomoc dziadków (czy szerzej opieka rodzinna) ma charakter nieformalny, nieodpłatny, wiąże się z emocjonalnym nacechowaniem więzi między członkami.

Opiekę nad wnukami sprawują więc przede wszystkim babcie (to wręcz preferowany model opieki nad najmłodszymi dziećmi). Polska w tym względzie wpisuje się w europejski styl sprawowania opieki nad wnukami, choć występują różnice w częstotliwości jej sprawowania. O ile w krajach Europy Północnej opieka ta ma charakter okazjonalny, tak w krajach Europy Południowej - charakter intensywny i regularny ${ }^{32}$. Stopień zaangażowania starszego pokolenia w opiekę nad dziećmi zależy od wieku babć, wieku dzieci (częściej gdy są w wieku przedszkolnym), wieku matek (im młodsze, tym częściej korzystają z pomocy babć), a także od aktywności zawodowej matek (im dłuższe godziny pracy, tym większa pomoc

29 P. Michoń, Transfery międzypokoleniowe w rodzinie, „Ruch Prawniczy, Ekonomiczny i Socjologiczny" 2012, nr 3, s. 243.

30 J. Brannen, P. Moss, A. Mooney, Working and Caring over the Twentieth Century. Change and Continuity in Four-Generation Families, New York 2004.

31 M. Kalbarczyk, A. Nicińska, Finansowe i niefinansowe transfery w próbie SHARE, „Polityka Społeczna” 2009, nr 4, s. 18.

32 To rodzina jest głównym dostawcą usług opiekuńczych. Oczywiście występują różnice w praktykach rodzinnych i wzorach solidarności rodzinnej związane z czynnikami „mikro-poziomu” (potrzeby i preferencje członków rodziny) oraz z czynnikami „makro-poziomu" (warunki ekonomiczne, polityka społeczna i usługi publiczne, kultura). Państwa i regiony Europy różnią się wzorcami międzygeneracyjnego wsparcia, postawą wobec roli kobiet i mężczyzn w rodzinie oraz ich zobowiązań do wspierania członków rodziny. Generalnie, kraje Europy Wschodniej i Południowej charakteryzuje większe poczucie obowiązku wobec rodziny i tradycyjne wartości rodzinne niż kraje Europy Zachodniej i Północnej. M. Jappens, J. Van Bavel, Regional family norms and child care by grandparents in Europe, „Demographic Research” 2012, no 27, s. 85-120; Zob. M. Szyszka, Polityka rodzinna dopełnieniem solidarności rodzinnej, „Studia Socjologiczne” 2017, nr 2(225). 
babć) $)^{33}$. Ale opieka nad wnukami to nie tylko realizacja funkcji opiekuńczej, lecz także przekazywanie różnego rodzaju kapitałów - ekonomicznego, genetycznego, uczuciowego, symbolicznego, ideologicznego, kulturowego, społecznego i ludzkiego $^{34}$. Seniorzy odgrywają nieocenioną rolę jako „nośnik” wiedzy, kultury, tradycji rodzinnych i doświadczenia życiowego, które przekazują młodemu pokoleniu ${ }^{35}$, mimo różnicy pokoleniowej. Dzięki aktywności w obszarze rodziny osoby starsze rzadziej odczuwają samotność i izolację społeczną, czują się potrzebni, co przekłada się na lepsze ich samopoczucie i codzienne funkcjonowanie.

Część seniorów wypełnia czas wolny pracą na rzecz innych. Choć generalnie zaangażowanie społeczne Polaków jest na niskim poziomie $(10,3 \%)$ i dominuje udział najmłodszych osób (15-17 lat -18,9\%), to osoby starsze (65+) także włączają się w prace społeczne ( $9,1 \%$ seniorów) i prace indywidualne, poza strukturami organizacyjnymi $(16,9 \%)^{36}$. Seniorzy są zresztą cenieni jako wolontariusze, ze względu na posiadane cechy - doświadczenie, dyspozycyjność, odpowiedzialność, obowiązkowość, zaangażowanie, spokój i cierpliwość. Realizują się w takich obszarach jak edukacja, zdrowie, kultura i sztuka, ubóstwo, czy praca z młodzieżą lub innymi osobami starszymi ${ }^{37}$.

Jakość życia polskich seniorów jest zróżnicowana. Zależy od płci, stopnia zaawansowania wieku, wykształcenia, miejsca zamieszkania. Jak wynika z danych Diagnozy Społecznej 2013 jakość życia seniorów jest w zakresie niektórych wymiarów lepsza, a w zakresie innych gorsza niż w młodszych pokoleniach. Lepsza jest jakość życia seniorów pod względem stresu i patologii, co jest naturalne, bowiem z wiekiem zmniejsza się liczba spraw i obszarów działań rodzących stres (np.

33 K. Hank, I. Buber, Grandparents Caring for Their Grandchildren. Findings from the 2004 Survey of Health, Ageing and Retirement in Europe, „Journal of Family Issues” 2009, no 30(1), s. 53-73; C. Igel, M. Brandt, K. Haberkern, M. Szydlik, Specialization between Family and State. Intergenerational Time Transfers in Western Europe, ,Journal of Comparative Family Studies" 2009, no 40(2), s. 203-226; M. Jappens, J. Van Bavel, Regional family norms and child care by grandparents in Europe, „Demographic Research” 2012, no 27, s. 85-120.

34 P. Szukalski, Wewnatrzrodzinne przeptywy międzypokoleniowe jako kategoria analityczna. Przegląd badań prowadzonych w krajach rozwiniętych, „Polityka Społeczna” 2002, nr 8, s. 16-20.

35 L. Prorok-Mamińska, Wptyw polityki społecznej na potrzeby rodziny w opiniach respondentów, w: Rodzina w zmieniającym się społeczeństwie polskim, red. W. WarzywodaKruszyńska, P. Szukalski, Łódź 2004, s. 190.

36 Wolontariat w organizacjach i inne formy pracy niezarobkowej poza gospodarstwem domowym 2011, GUS, Warszawa 2012, s. 27-28; 48.

37 M. Adamczyk, Aktywnie ku emeryturze, dz. cyt., s. 93-94. 
wychowanie dzieci, praca, małżeństwo, załatwianie spraw urzędowych), spada także stosowanie używek. Porównywalny jest poziom dobrostanu społecznego, zaś gorsza jest jakość życia seniorów w pozostałych wymiarach: kapitału społecznego, dobrostanu psychicznego, poziomu cywilizacyjnego i dobrobytu oraz - co oczywiste - dobrostanu fizycznego. Jednakże, jak twierdzą autorzy raportu, „nie ma dziś w Polsce jednego wymiaru jakości życia. Ci, którym nie wiedzie się materialnie i nie są zbyt nowocześni, mogą mimo to cieszyć się innymi względami losu - wolnością od patologii i doświadczaniem niewielkiego stresu. I to jest właśnie mocna strona seniorów"38. Wydaje się również, że sami seniorzy lepiej oceniają starość jako etap życia niż osoby młodsze, jeszcze pracujące, a niższa ocena może wynikać ze wskazanych wyżej obaw przed wejściem w ten okres życia.

\section{Seniorzy wyzwaniem dla polityki rodzinnej}

Starzenie się społeczeństwa, jak wykazano wyżej, stanowi wielowymiarowy problem i wyzwanie dla społeczeństwa i rządu. Konsekwencje tego procesu ponosi już obecne pokolenie, a problem będzie narastał (zgodnie z prognozami demograficznymi). Dlatego niezbędne są inicjatywy zmierzające z jednej strony do przywrócenia „równowagi demograficznej” w społeczeństwie (wzrost liczby dzieci i przyrost naturalny), z drugiej zaś - inicjatywy skierowane do osób starszych w celu poprawy jakości ich życia oraz aktywizacji ekonomicznej, kulturalnej i społecznej. Zmienia się bowiem oblicze polskiej „starości demograficznej”. W wiek starszy wkraczają (a w przyszłości coraz liczniej będą wkraczać) roczniki osób lepiej wykształconych, dysponujących większym kapitałem zdrowia, społecznym i kulturalnym, ale też mniejszą siecią rodzinną. Celem jest zatem propagowanie aktywnego starzenia się, dostosowanego do potrzeb i oczekiwań najstarszego pokolenia (jak i przyszłych pokoleń).

$\mathrm{Z}$ tego też względu w ostatnich latach intensyfikowano działania na rzecz seniorów (zob. tab. 1), opracowując politykę senioralną, rozumianą jako ogół działań w okresie całego życia człowieka, prowadzących do zapewnienia warunków wydłużenia aktywności, zarówno zawodowej, jak i społecznej, oraz samodzielnego, zdrowego, bezpiecznego i niezależnego życia osób starszych ${ }^{39}$. W 2013 r. powołana została Rada ds. Polityki Senioralnej jako organ pomocniczy Ministra Pracy

38 P. Błędowski, J. Czapiński, Aktywność społeczna osób starszych ..., dz. cyt., s. 84-89.

39 Założenia Dtugofalowej Polityki Senioralnej w Polsce na lata 2014-2020, Warszawa 2014, s. 4.

https://www.mpips.gov.pl/seniorzyaktywne-starzenie/zalozenia-dlugofalowej-polityki-senioralnej-w-polsce-na-lata-20142020/ [dostęp 14.01.2017 r.]. 
i Polityki Społecznej. Przyjęto Założenia Długofalowej Polityki Senioralneje, w której za kluczowe obszary działań przyjęto zdrowie i samodzielność, aktywność zawodową, aktywność edukacyjną, społeczną i kulturalną, srebrną gospodarkę oraz relacje międzypokoleniowe.

Tabela 1. Instrumenty polityki rodzinnej w ramach wsparcia i aktywizacji seniorów

\begin{tabular}{|c|c|c|}
\hline & Instrumenty polityki rodzinnej & Podstawa prawna \\
\hline \multirow{5}{*}{$\begin{array}{l}\text { Wsparcie } \\
\text { i aktywi- } \\
\text { zacja osób } \\
\text { starszych }\end{array}$} & świadczenia opiekuńcze & $\begin{array}{l}\text { Ustawa o pomocy społecznej z } 12 \text { marca } \\
2014 \text { r. (Dz. U. z } 2004 \text { r., nr 64, poz. 593) }\end{array}$ \\
\hline & $\begin{array}{l}\text { włączenie osób starszych w życie } \\
\text { lokalnej społeczności }\end{array}$ & $\begin{array}{l}\text { Rządowy Program Aktywności } \\
\text { Społecznej Osób Starszych na lata 2014- } \\
2020 \text { (Program ASOS) } \\
\end{array}$ \\
\hline & $\begin{array}{l}\text { podnoszenie kwalifikacji osób } \\
50+\text { i promowanie aktywności } \\
\text { zawodowej }\end{array}$ & Program „Solidarność pokoleń” \\
\hline & $\begin{array}{l}\text { dofinansowanie dziennych domów } \\
\text { dla osób } 60+\text { nieaktywnych } \\
\text { zawodowo }\end{array}$ & $\begin{array}{l}\text { Program „Senior-WIGOR” na lata } \\
2015-2020\end{array}$ \\
\hline & $\begin{array}{l}\text { zadania w odniesieniu do osób } \\
\text { starszych: aktywne starzenie się } \\
\text { w dobrym zdrowiu, większy udział } \\
\text { w życiu społecznym i solidarność } \\
\text { międzypokoleniowa }\end{array}$ & $\begin{array}{l}\text { Założenia Długofalowej Polityki } \\
\text { Senioralnej w Polsce na lata 2014-2020 }\end{array}$ \\
\hline
\end{tabular}

Źródło: Opracowanie własne na podstawie https://rodzina.gov.pl.

Jednym z obszarów wsparcia jest pomoc seniorom w ich codziennym funkcjonowaniu. Oczywiście kluczową rolę odgrywa w tym względzie rodzina (dzieci). $60 \%$ osób starszych korzysta ze wsparcia młodego pokolenia w zakresie prac domowych, niemal co druga osoba starsza korzysta z pomocy w robieniu zakupów i załatwianiu spraw urzędowych, zaś $41 \% \mathrm{w}$ zakresie opieki pielęgnacyjnej ${ }^{41}$. Niejednokrotnie jednak samotni (choć niekoniecznie) seniorzy, będąc aktywni i samodzielni, korzystają z pomocy instytucjonalnej. Program „Senior-Wigor” wspiera (dofinansowuje) dzienne domy dla osób 60+ niepracujące zawodowo, w których osoby starsze mogą aktywnie spędzać czas.

40 https://www.mpips.gov.pl/seniorzyaktywne-starzenie/zalozenia-dlugofalowej-polityki-senioralnej-w-polsce-na-lata-20142020/ [dostęp 14.01.2017 r.].

$41 \quad$ P. Czekanowski, Rodzina w życiu osób starszych i osoby starsze w rodzinie, w: Polska starość, red. B. Synak, Gdańsk 2003, s. 164. 
Niezmiernie istotnym działaniem jest podnoszenie kwalifikacji osób $50+\mathrm{i}$ promowanie ich aktywności zawodowej. Program „Solidarność pokoleń” skierowany jest więc do osób młodszych, które dopiero za kilka lub kilkanaście lat będą wchodzić w wiek przedemerytalny. Zakłada on z jednej strony promowanie uczenia się przez całe życie, rozwój oferty edukacyjnej i wspieranie pracowników 50+ w rozwijaniu kompetencji i kwalifikacji, z drugiej zaś budowanie przyjaznego środowiska pracy dla pracowników 50+, promowanie aktywności zawodowej, wspieranie aktywnego starzenia się i aktywności zawodowej osób w wieku przedemerytalnym ${ }^{42}$. Ten obszar działania wpisuje się w założenia srebrnej gospodarki (silver economy), systemu ekonomicznego ukierunkowanego na wykorzystanie potencjału osób starszych przy uwzględnieniu ich potrzeb. Zatem i w tej kwestii istotna jest dualność podejścia - skoncentrowane na potrzebach starszego pokolenia w kontekście potrzeb i popytu z jednej strony, oraz wykorzystanie specyficznych cech ludzi starszych dla zwiększenia ich aktywności i wykorzystania ich potencjału $z$ drugiej ${ }^{43}$.

Ważnym uszczegółowieniem polityki senioralnej jest Program ASOS, który zakłada pełniejsze włączenie osób starszych w życie lokalnych społeczności, wykorzystanie ich potencjału w relacjach z młodszymi pokoleniami oraz podtrzymanie aktywności seniorów również po zakończeniu kariery zawodowej. Program oferuje dotacje finansowe w ramach czterech priorytetowych obszarów: edukacja osób starszych, aktywność społeczna promująca integrację wewnątrz- i międzypokoleniową, partycypacja społeczna osób starszych oraz usługi społeczne dla osób starszych ${ }^{44}$.

Stosunkowo nowym podejściem związanym z procesem starzenia się społeczeństwa jest kwestia przygotowania się do emerytury. Dotyczy ona wprawdzie młodszych osób (w tzw. wieku przedstarczym $45-59$ lat), ale w znaczący sposób decyduje

42 https://rodzina.gov.pl/seniorzy/program-solidarnosc-pokolen [dostęp 14.01.2017 r.].

43 Zob. www.silvereconomy-europe.org; S. Golinowska, ,, Srebrna gospodarka” i miejsce w niej sektora zdrowotnego. Koncepcja i regionalne przykłady zastosowania, „Zdrowie Publiczne i Zarządzanie" 2011, vol. 1, s. 76-85.

44 Promocja działań na rzecz osób starszych przynosi efekty w postaci wielości podejmowanych inicjatyw. W 2015 r. w ramach Programu ASOS zrealizowano łącznie 469 projektów w całej Polsce, w zadaniach uczestniczyło 286 tys. beneficjentów, a łączna suma dofinansowania wyniosła $38 \mathrm{mln}$ zł. 152 projekty w ramach Priorytetu I (110 tys. beneficjentów, $117 \mathrm{mln}$ zł dotacji), 198 projektów w ramach Priorytetu II (49 tys. beneficjentów, $153 \mathrm{mln}$ zł dotacji), 58 projektów w ramach Priorytetu III (39 tys. beneficjentów, 54 mln zł dotacji) oraz 61 projektów w ramach Priorytetu IV (88 tys. beneficjentów, 56 mln zł dotacji, w tym 24 projekty UTW), https://rodzina.gov.pl/seniorzy/program-asos [dostęp 14.01.2017 r.]. 
o podejściu do starości i o jakości owej starości. Z badania BALL (Be Active through Lifelong Learning) wynika, iż w Polsce brakuje działań wspierających zarówno stopniowe przejście na emeryturę, jak i wspomagających przygotowanie planu emerytalnego. A przecież „przygotowanie do emerytury powinno być procesem stopniowym, umożliwiającym uzyskanie jak najbardziej optymalnej i korzystnej sytuacji dla przyszłego emeryta" ${ }^{\not 5}$. Okazuje się jednak, że ponad połowa badanych (58\%) nie otrzymała żadnej pomocy w stopniowym przejściu na emeryturę. Spośród zaś osób, które takowe wsparcie uzyskało, $12 \%$ dostało propozycję przejścia na pracę w niepełnym wymiarze godzin, 10\% propozycję zmiany zakresu obowiązków i podjęcia łatwiejszej (lżejszej) pracy, a 8\% negocjowało możliwość pracy dłuższej niż ustawowy wiek emerytalny. W przypadku natomiast działań wspomagających przygotowanie planu emerytalnego (przygotowanie finansowe) ponad $2 / 3$ badanych (68\%) nie otrzymało żadnego wsparcia od pracodawcy. Nieliczni brali udział w kursach, czy seminariach, których celem było planowanie emerytury (jak oszczędzać, plan świadczeń emerytalnych), czy też otrzymali od pracodawcy materiały szkoleniowe (łącznie ok. 9\%). Co więcej, brakuje także inicjatyw ze strony instytucji pomocy społecznej. Jedynie niewielki odsetek badanych $(9 \%$ osób pracujących i 3\% emerytów) ma wiedzę na temat działań wspomagających przejście na emery turę prowadzonych przez lokalne oddziały pomocy społecznej. A jak się okazuje, blisko trzy czwarte badanych chciałoby uczestniczyć w takich zajęciach edukacyjnych, tym bardziej, że $8 \%$ badanych emerytów potrzebowało pomocy psychologa po przejściu na emeryturę ${ }^{46}$. Być może nie jest to duża liczba (co jest $z$ drugiej strony optymistyczne), ale wskazuje, jak trudny i problematyczny może być czas wygaszania aktywności zawodowej i konieczności radzenia sobie w nowej rzeczywistości bez dotychczasowej rutyny i codziennych obowiązków.

Aktualnie coraz częściej dostrzega się także potrzebę wsparcia pracujących osób w wieku 50+ w zakresie godzenia życia zawodowego z rodzinnym. Osoby te, określane mianem sandwich generation, są podwójnie obciążone koniecznością niesienia pomocy swoim dzieciom i wnukom oraz rodzicom. Jak wynika z badań Polsenior, osoby w wieku 55-59 świadczą w rodzinie zróżnicowaną w formie pomoc. Pomagają finansowo (dzieciom $-77 \%$, wnukom $-18 \%$, rodzeństwu $-13 \%$ i rodzicom $-10 \%$ ), w prowadzeniu gospodarstwa domowego (dzieciom $-46 \%$ i rodzicom - 19\%), w pielęgnacji i opiece w chorobie (dzieciom - 23\%, wnukom $-17 \%$ i rodzicom $-47 \%$ ), udostępniają mieszkanie (dzieciom - 72\%, wnukom - 23\% i rodzicom - 11\%), załatwiają sprawy urzędowe (dzieciom - 37\% i rodzicom $-37 \%$ ), udzielają także wsparcia psychicznego (dzieciom - 55\%, wnukom - 13\%

45 M. Adamczyk, Aktywnie ku emeryturze, dz. cyt., s. 107.

46 Tamże, s. 107-113. 
i rodzicom $-26 \%)^{47}$. Szeroki wachlarz rodzajów wsparcia oferowanego osobom bliskim stanowi rzeczywiste obciążenie polskich pięćdziesięciolatków (zwłaszcza kobiet). Duży wysiłek fizyczny i psychiczny może prowadzić do „wypalenia opiekuńczego" - permanentnego zmęczenia i swoistego znużenia powtarzalnością tych samych czynności ${ }^{48}$. Dlatego też wskazuje się na konieczność opracowania rozwiązań systemowych wspierających osoby opiekujące się osobami starszymi w celu umożliwienia im łączenia pracy zawodowej i świadczenia opieki w rodzinie ${ }^{49}$.

Starzenie się społeczeństwa i procesy z nim związane wymagają zatem kompleksowego i strategicznego podejścia rządu w kwestii rozwiązywania trudności coraz większej populacji seniorów. Jak wskazano wyżej, podejmowane są inicjatywy w tym kierunku. Ze względu jednak, iż stosunkowo późno dostrzeżono problem, wielość kwestii i ich narastanie wymaga z zarówno diagnozy, jak i konkretnych propozycji rozwiązań. Jakie zatem wyzwania stoją przed społeczeństwem i rządem w kwestii starzenia się i starości? Jakie obszary wymagają pilnych rozwiązań? Analizy ${ }^{50}$ wskazują, iż koncentracja działań powinna obejmować:

- zapewnienie osobom w wieku przedemerytalnym oraz seniorom równego dostępu do rynku pracy, rozwój systemu dokształcania się osób w wieku okołoemerytalnym;

- popularyzowanie w zakładach pracy dobrych praktyk zarządzania wiekiem, w celu efektywnego wykorzystania wiedzy i doświadczenia starszych pracowników;

47 B. Szatur-Jaworska, Sytuacja rodzinna i więzi rodzinne ludzi starszych i osób na przedpolu starości, w: Aspekty medyczne, psychologiczne, socjologiczne i ekonomiczne starzenia się ludności w Polsce, red. M. Mossakowska, A. Więcek, P. Błędowski, Poznań 2012, s. 435.

48 A. Kotlarska-Michalska, Wielość ról rodzinnych pokolenia sandwicz, „Societas/ Communitas" 2016, nr 1(21), s. 71.

49 Zob. Założenia Dlugofalowej Polityki Senioralnej w Polsce na lata 2014-2020, Warszawa 2014, s. 21.

50 Założenia Dtugofalowej Polityki Senioralnej w Polsce na lata 2014-2020, Warszawa 2014; P. Błędowski, J. Czapiński, Aktywność społeczna osób starszych w kontekście percepcji Polaków. Diagnoza Społeczna 2013, Warszawa 2014; M. Adamczyk, Aktywnie ku emeryturze, Lublin 2015; Stres okołoemerytalny w ujęciu zdrowotnych, ekonomicznym, psychologicznym i społecznym, Raport, red. F. Raciborski, B. Smoliński, Warszawa 2013; M. Racław, M. Rosochacka-Gmitrzak, Proces starzenia się w kontekście wyzwań demografii, polityki społecznej oraz doniesień badawczych, w: Aktywny senior - najlepszy rzecznik swoich społeczności, Warszawa 2013; Jakiej pomocy potrzebuja osoby starsze i kto jej udziela?, Komunikat CBOS, Warszawa 2016; J. Krzyszkowski, Pomoc społeczna wobec starzenia się społeczeństwa polskiego, „Przegląd Socjologiczny” 2013, t. 62, nr 13. 
- dostosowanie warunków mieszkaniowych seniorów do ich potrzeb; podnoszenie dobrostanu osób starszych (w przypadku mężczyzn koncentracja na czynnikach decydujących o długości życia, w przypadku kobiet - na czynnikach decydujących o jakości życia);

- podniesienie poziomu aktywności fizycznej seniorów oraz stworzenie systemu wczesnej rehabilitacji zapobiegającej powstawaniu i pogłębianiu się niepełnosprawności, ze szczególnym uwzględnieniem potrzeb najstarszej grupy seniorów (80+);

- rozszerzenie i popularyzacja działań profilaktycznych w zakresie zachowań prozdrowotnych seniorów oraz młodszych generacji, poprawa ilościowa i jakościowa systemu opieki zdrowotnej;

- przygotowanie do związanego z procesem podwójnego starzenia się ludności szybkiego wzrostu zapotrzebowania na świadczenia zdrowotne oraz opiekuńcze i pielęgnacyjne;

- rozszerzenie oferty usług opiekuńczych, rozwój alternatywnych form opieki dla osób starszych, podnoszenie kwalifikacji opiekunów (w tym opiekunów nieformalnych);

- $\quad$ wsparcie rodzin osób starszych w zakresie świadczenia opieki;

- zapewnienie stabilnego systemu finansowania świadczeń emerytalnych i opiekuńczych;

- zapobieganie i zwalczanie ubóstwa oraz przejawów wykluczenia społecznego, finansowego i cyfrowego;

- aktywizacja społeczna seniorów, integracja i ułatwianie kontaktów międzypokoleniowych, rozwój organizacji trzeciego sektora (wolontariatu);

- rozwój oferty edukacyjnej dla osób starszych, rozwój sieci Uniwersytetów Trzeciego Wieku i innych form spotkań (np. Kluby Seniora);

- kształtowanie opinii publicznej, propagowanie pełnego obrazu starości oraz zwalczanie stereotypów i dyskryminacji ze względu na wiek (przeciwdziałanie gerontofobii i ageismowi), zaangażowanie i współpraca wielu podmiotów;

- kreowanie pozytywnego wizerunku ludzi starych poprzez używanie niewartościującego (i nieinfantylizującego) języka i pokazywanie różnorodnych stylów życia i aktywności osób starszych;

- rozwój działań polityki rodzinnej, podkreślających rolę i wartość najstarszych członków rodziny;

- popularyzacja działań w zakresie efektywnego przygotowania się do emerytury.

Generalnie, kształt polityki senioralnej państwa zakłada trzy różne perspektywy: indywidualną (polityka wobec ludzi starszych), faz życia (polityka wobec starości) 
oraz trwającego procesu (polityka wobec starzenia się ludności). Nadrzędnym celem wydaje się być akcentowanie procesu starości jako cywilizacyjnego osiągnięcia i skutku poprawy jakości życia społeczeństw, aby zminimalizować obecne podejście, traktujące starość jako cywilizacyjne obciążenie.

\section{Zakończenie}

Istotą starości jest to, iż jest nieunikniona. Niestety, współcześnie kult młodości i kanony piękna odsuwają starzenie się w obszary niezauważalności. Dlatego też konieczna jest zmiana miejsca starości i starzenia się w sferze społecznych zainteresowań - z obszaru marginalnego na centralne. Ważne jest podkreślanie, iż starość to naturalny i nieodwracalny proces, który niesie określone konsekwencje w płaszczyźnie mikro- i makrospołecznej. Tym samym konieczne jest kompleksowe i syntetyczne ujęcie omawianej problematyki. Punktem wyjścia wydaje się być spojrzenie na osoby starsze jako na grupę zróżnicowaną, twórczą, wnoszącą istotny wkład w życie społeczne i ekonomiczne. Niemałą rolę może odegrać polityka rodzinna, podkreślająca wagę rodziny i wszystkich jej członków. Rodzina bowiem jest dla ludzi starszych najważniejszą grupą odniesienia, decydującą o subiektywnym bilansie życia, samoocenie i poczuciu wartości. Stąd tak istotne jest budowanie pozytywnych relacji międzypokoleniowych, aby zminimalizować ryzyko negatywnych następstw w momencie wkraczania w ostatni etap życia.

\section{Bibliografia}

Abramowska-Kmon A., O nowych miarach zaawansowania procesu starzenia się ludności, „Studia Demograficzne” 2011, nr 1(159), s. 3-22.

Adamczyk M., Aktywnie ku emeryturze, Lublin 2015.

Aspekty medyczne, psychologiczne, socjologiczne i ekonomiczne starzenia sięludności w Polsce, red. M. Mossakowska, A. Więcek, P. Błędowski, Poznań 2012.

Błędowski P., Czapiński J., Aktywność społeczna osób starszych w kontekście percepcji Polaków. Diagnoza Społeczna 2013, Warszawa 2014.

Brannen J., Moss P., Mooney A., Working and Caring over the Twentieth Century. Change and Continuity in Four-Generation Families, New York 2004.

Czekanowski P., Rodzina $w$ życiu osób starszych i osoby starsze $w$ rodzinie, w: Polska starość, red. B. Synak, Gdańsk 2003.

Golinowska S., ,Srebrna gospodarka” i miejsce w niej sektora zdrowotnego. Koncepcja i regionalne przyktady zastosowania, „Zdrowie Publiczne i Zarządzanie" 2011, vol. 1, s. 76-85. 
Hank K., Buber I., Grandparents Caring for Their Grandchildren. Findings from the 2004 Survey of Health, Ageing and Retirement in Europe, ,Journal of Family Issues" 2009, no 30(1), s. 53-73.

Hrynkiewicz J., Aktualna sytuacja demograficzna Polski, w: Perspektywy demograficzne jako wyzwanie dla polityki ludnościowej, red. J. Hrynkiewicz, A. Potrykowska, Rządowa Rada Ludnościowa, Warszawa 2016, s. 14-23.

https://rodzina.gov.pl/seniorzy/program-asos [dostęp 14.01.2017 r.].

https://rodzina.gov.pl/seniorzy/program-solidarnosc-pokolen [dostęp 14.01.2017 r.]. Igel C., Brandt M., Haberkern K., Szydlik M., Specialization between Family and State. Intergenerational Time Transfers in Western Europe, „Journal of Comparative Family Studies" 2009, no 40(2), s. 203-226.

Jakiej pomocy potrzebuja osoby starsze i kto jej udziela?, Komunikat CBOS, Warszawa 2016.

Jappens M., Van Bavel J., Regional family norms and child care by grandparents in Europe, „Demographic Research” 2012, no 27, s. 85-120.

Kalbarczyk M., Nicińska A., Finansowe i niefinansowe transfery w próbie SHARE, „Polityka Społeczna” 2009, nr 4, s. 13-19.

Kotlarska-Michalska A., Wielość ról rodzinnych pokolenia sandwicz, „Societas/ Communitas" 2016, nr 1(21), s. 57-80.

Krzyszkowski J., Pomoc społeczna wobec starzenia się społeczeństwa polskiego, „Przegląd Socjologiczny” 2013, t. 62, nr 13, s. 9-31.

Ludność w wieku 60+. Struktura demograficzna i zdrowie, GUS, Warszawa 2016; http://stat.gov.pl/obszary-tematyczne/ludnosc/ludnosc/ludnosc-w-wieku-60-struktura-demograficzna-i-zdrowie,24,1.html [dostęp 14.01.2017 r.].

Michoń P., Transfery międzypokoleniowe $w$ rodzinie, „Ruch Prawniczy, Ekonomiczny i Socjologiczny" 2012, nr 3, s. 237-251.

Polacy wobec własnej starości, Komunikat CBOS, Warszawa 2012.

Portret społeczno-demograficzny seniorów, Komunikat CBOS, Warszawa 2016.

Prognoza ludności na lata 2014-2050, GUS, Warszawa 2014.

Prorok-Mamińska L., Wpływ polityki społecznej na potrzeby rodziny w opiniach respondentów, w: Rodzina w zmieniajacym się społeczeństwie polskim, red. W. Warzywoda-Kruszyńska, P. Szukalski, Łódź 2004, s. 175-196.

Racław M., Rosochacka-Gmitrzak M., Proces starzenia się, w kontekście wyzwań demografii, polityki społecznej oraz doniesień badawczych, w: Aktywny seniornajlepszy rzecznik swoich społeczności, Warszawa 2013, 9-22.

Seniorzy a młodsze pokolenia - problemy życia codziennego, Komunikat CBOS, Warszawa 2015. 
Stańczak J., Szałtys D., Sytuacja demograficzna Polskina tle Europy, w: Perspektywy demograficzne jako wyzwanie dla polityki ludnościowej, red. J. Hrynkiewicz, A. Potrykowska, Rządowa Rada Ludnościowa, Warszawa 2016, s. 43-47.

Stres okotoemerytalny $w$ ujęciu zdrowotnych, ekonomicznym, psychologicznym i społecznym, Raport, red. F. Raciborski, B. Smoliński, Warszawa 2013.

Sytuacja demograficzna osób starszych i konsekwencje starzenia się ludności Polski w świetle prognozy na lata 2014-2050, GUS, Warszawa 2014.

Szatur-Jaworska B., Sytuacja rodzinna $i$ więzi rodzinne ludzi starszych i osób na przedpolu starości, w: Aspekty medyczne, psychologiczne, socjologiczne i ekonomiczne starzenia się ludności w Polsce, red. M. Mossakowska, A. Więcek, P. Błędowski, Poznań 2012, s. 435-448.

Szukalski P., Wewnatrzrodzinne przeptywy międzypokoleniowe jako kategoria analityczna. Przeglad badań prowadzonych w krajach rozwiniętych, „Polityka Społeczna" 2002, nr 8, s. 16-20.

Szyszka M., Polityka rodzinna dopetnieniem solidarności rodzinnej, „Studia Socjologiczne" 2017, nr 2(225), 241-266.

Trwanie życia w 2015 r., GUS, Warszawa 2016.

Waligórska M., Witkowski J., Prognoza demograficzna Polski do 2050 roku-nowe ujęcie, w: Perspektywy demograficzne jako wyzwanie dla polityki ludnościowej, red. J. Hrynkiewicz, A. Potrykowska, Rządowa Rada Ludnościowa, Warszawa 2016, s. 50-66.

Wolontariat $w$ organizacjach $i$ inne formy pracy niezarobkowej poza gospodarstwem domowym 2011, GUS, Warszawa 2012.

Założenia Długofalowej Polityki Senioralnej w Polsce na lata 2014-2020, Warszawa 2014; https://www.mpips.gov.pl/seniorzyaktywne-starzenie/zalozenia-dlugofalowej-polityki-senioralnej-w-polsce-na-lata-20142020/ [dostęp 14.01.2017 r.].

\section{Małgorzata Szyszka: Seniors and aging in Polish family policy}

\section{Summary}

Contemporary social problems include the aging process and the growing elderly population. The consequences of these phenomena are individual and social in nature. They define the image of Polish society (decreasing population, decreasing fertility rates, the increasing number of elderly people, the decreasing number of children, adolescents and people of working age). They present a challenge on the one hand to the government - how to organize help and care for seniors - and, on the other hand, to the seniors themselves and their families how to improve the quality of their lives. 
The article discusses the aging process of the society, a description of a Polish senior citizen, and a family policy actions aiming at supporting and activation of the elderly.

Keywords: old age, aging process of Polish society, family policy, senior, pensioner 